\title{
INTRODUCING TAIWAN CHINESE CONTEMPORARY SHORT STORIES IN POLAND: CULTURAL CONTEXTS, FIELDS OF REPRESENTATION AND EQUIVALENCE*
}

\begin{abstract}
A b s tract. This paper investigates basic issues related to the translation of Taiwanese literature in Poland. Assuming the Juliane House's definitions that translation is "a cognitive procedure and a social, cross-linguistic and cross-cultural practice", I discuss this matter theoretically and practically on three major levels pertaining to literature and communication between both languages and cultures. According to the system approach, the model is divided into: 1) Source/Taiwan literature; 2) Target/Polish reader; 3) Mediation/Translator and is imbued with reflection on representation, cultural and political context and equivalence in translation's polysystem. In the practical dimension the analysis refers to a particular case, which is the preparation of the first Polish translation of Taiwanese Contemporary Short Stories. This article also reveals the decision-making process concerning the most representative selection of different genres, periods, stylistics, authors and messages. The anthology of contemporary Taiwanese short stories ${ }^{1}$ debated here is being compiled from the perspective of translators, who are Sinologists teaching at the University of Warsaw. In line with the concepts of anthology theoreticians, this kind of academic edition with references and critical comment supports the Polish reader in the process of correct decoding of the text and many contexts of Taiwanese literature.
\end{abstract}

Keywords: translation; Taiwan literature; Polish recipient; representation; equivalence; crosscultural mediation; Anthology of Taiwanese Short Stories.

Prof. Dr. habil. Lidia KaSARetzo - University of Warsaw, Faculty of Oriental Studies, Department of Sinology; correspondence address - e-mail: lidia.kasarello@uw.edu.pl; ORCID: https://orcid.org/0000-0002-9206-6300.

* Some of the paper's points were presented at the International Conference on Taiwanese Literature Translation, National Chengchi University, Taipei, November 2019.

${ }^{1}$ In Polish: Na drugim brzegu. Antologia wspótczesnych opowiadań tajwańskich, red. Lidia Kasarełło, Państwowy Instytut Wydawniczy, 2020 [On the Other Shore: Anthology of Contemporary Taiwanese Short Stories, ed. Lidia Kasarełło, Państwowy Instytut Wydawniczy, 2020]. 
Over the centuries, the approach to translation theories has changed (Steiner 34) and nowadays after 'paradigm shift' or the 'cultural turn' many new theories such as the polysystem theory and skopos have emerged.

\section{TRANSLATION THEORY AND METHODOLOGY}

The polysystem theory based on Russian Formalist thinking offers a model for describing the functions of the literary system that operate on three mutual interacting levels: linguistic,cultural and social. Literature is therefore a subsystem of society and it interacts with other systems (Lefevere 16).

In skopos theory attention is shifted from the linguistic and formal approach to functionally and socio-culturally oriented concepts of translation.

Most of the recent proposition in translation theory is concerned with describing appropriate translation methods and strategies for analyzing linguistic issues, text production, cognitive activity, intercultural communication, ethics, training and technology. These theories differ in terms of perspectives, approaches, principles and procedures.

Philological theories focus on literary texts; linguistic theories concentrate on structural differences between source and target language; sociolinguistic theories emphasize communication process (Nida 66-79), with underlining the receptor's special role in the translation process. ${ }^{2}$

In general, the traditional essentialist approach (based on the romantic notion) considering literature as an autonomous and independent domain competes with concepts that explore literature in a broader social and cultural framework. Traditionalists, due to Platonic-Christian metaphysics, see the author as a quasi-divine 'creator' but they ignore the translator who only copies the 'sacred' original (Ketkar).

Process-oriented approaches to translation give priority to source text segments (Baker and Saldanha 305; Malmkjar 286). Product-oriented approaches such as the 'descriptive translation' theory of Gideon Toury emphasizes that translations are facts of one system only: the target system and its culture (Ketkar).

Within sociological approaches sociolinguist and sociologically sensitive models of translation dominate. Due to the concept that literature is a social

\footnotetext{
${ }^{2}$ In applying other analytical criteria in translating theory, it is also possible to differentiate between: the sociolinguistic approach (Zohar, Toury); the communicative approach ('theory of sense' of Seleskovitch and Lederer); the hermeneutic approach (Steiner) the linguistic approach (Vinay, Darbelnet, Austin, Vegliante, and Mounin ); the literary approach and the semiotic approach.
} 
institution related to other social institutions translator explores the connections between literature, politics, community, poetics, culture and history.

Some translation sociologists focusing on the role of translation in articulating "socio-political and symbolic claims of the nation-state" (Baker 279) draw inspiration from Bourdieu's concept of capital and power resources and prestige (Baker and Saldanha 156).

Similarly, literary theories like New Historicism investigate power relations in literary work.

In his book Sitting Translation, History, Post-Structuralism, and the Colonial Context Tejaswini Niranjana claims: "literary texts as space where power relations are made visible. In a post-colonial context, the problematic of translation becomes a significant site for raising questions of representation, power, and historicity" (as cited in Ketkar).

Stating that literary translation between languages are hierarchically related opens the door to examining the political dimension.

Bassnett and Trivedi (1-4) refer to the hierarchic opposition between the European colonizer culture and the colonized culture, indicating that it is reflected in translated works.

\section{CONTEXT OF SOURCE AND RECEPTOR SYSTEMS:} TAIWANESE AUTHORS VS POLISH READERS

Until now, ${ }^{3}$ no significant translation of Taiwanese literature has been available on the Polish publishing market. Taiwanese literature refers to literature written by Taiwanese in Taiwanese Han (Hokkien, Hakka and Mandarin), Japanese and Austronesian languages although in this case we are only dealing with hanyu texts. ${ }^{4}$

Thanks to the cooperation with Państwowy Instytut Wydawniczy (PIW) publishing house, sinologists gained a chance to prepare a publishing project

\footnotetext{
${ }^{3}$ In 2018, Polish publishing hose Kwiaty Orientu published the translation of San Mao 三毛 (1943-1991) 撒哈拉的故事 Sahala de gushi (The Stories of the Sahara) as San Mao, Saharyjskie $d n i$, trans. Jarosław Zawadzki, Kwiaty Orientu, 2018.

Unfortunately, all these stories have an autobiographical character and describe San Mao experiences living in the Sahara together with her Spanish husband. In 2012, Wydawnictwo Oficyna published two illustrated books by Jimmy Liao, unnoticed and classified as child's literature: Jimmy Liao. Dźwięki kolorów [Sound of Colors]. Trans. Katarzyna Sarek, Wydawnictwo Oficyna, 2012; Jimmy Liao. Księżyc zapomniat [When the Moon Forgot]. Trans. Katarzyna Sarek, Wydawnictwo Oficyna, 2012.

${ }^{4}$ Almost no Poles know Hakka Hokkien and Austronesian languages.
} 
for the first anthology of contemporary Taiwanese literature. Its preparation required the consideration of many important issues related to making a responsible and possibly representative selection of Taiwanese literature. The process of transferring a literary text from Taiwanese and Chinese culture to Polish involves a lot of actions. The text must be chosen, translated, edited, promoted and distributed.

The construction of the first anthology of Taiwanese literature in Polish seems to be a major challenge. Usually it is up to the publisher to determine the strategy, but in this case, it is the scientific editor who proposes the content of the volume. Of course, theoretically, an editor may prefer to publish a novel by an author who has achieved success in the world, which was the case with Nobel Prize winners Mo Yan (莫言) and Gao Xingjian (高行 健). For years, however, publishers were not particularly interested in editing anthologies of Chinese contemporary literature, not to mention the writings of Malaysia, Honkong, Vietnam, Burma, and Laos.

The publisher's acceptance of the selection proposed by the translator came with demands for additional argumentation and most often the delivery of the proposed texts in existing English translations. This is typical for promotion of lesser-known regional literature, which is often associated with financial risk to the publisher. Researchers increasingly point to the need for a paradigm shift in publishing policies for translating foreign literature.

Moreover, Schulte advocates a new kind of anthology, presented from the translator's perspective ("International Literature" 143). There is no doubt that the translator is fully familiar with the language, literature, author and, most of all, with the cultural and political context of the source text. His selection should be valuable in the process of spreading world literature in Poland. Some theorists argue that the translator, in his multidimensional work, has to transcend the level of literary limitation and introduce intellectual frames of reference (Schulte, "International Literature" 142). In one of his interviews, David Der-wei Wang emphasizes the importance of the translator as writer because translation is itself an act of creativity (Chun-yu Lu).

If we accept the claim that an anthology is a great metaphor and its strength depends on the conceptual assumption of the publisher (Schulte, "International Literature" 142), we should appreciate the importance of a proper selection of literary texts in the source (Chinese) language. The shift of responsibility from publisher to an expert on Taiwanese literature makes the knowledge of the Taiwanese context a key issue. Obviously, the translator's interest or enthusiasm for particular work also has a role to 
play. Usually, the translation of Taiwanese literature is initiated by the translators themselves, who are often the sinologist, as in the cases of Göran Malmqvist, Howard Goldblatt, and John Balcom.

Finally, selection decisions may reveal the literary-translation actor's identity and ideology which it is linked to ethics (Baker 157). It can also reveal their aesthetic preferences and individual taste. Therefore, in this case, academic editor who is also an expert and translator must carefully analyze several issues. First, in mediating, he or she must be aware of the existence of two different cultural backgrounds with social, linguistic, political and aesthetic connotations.

To simplify, we are dealing with two systems - Taiwan and Poland. The selection should be based on analysis of two fundamental components; for Taiwan it is a matter of representation, and for Poland, of reception. The issue of representation relates to the selection of genres and authors, and later, the selection of possible constellations, from different periods, schools, currents, themes and phenomena in the Taiwanese literary space.

Finally, the anthology $\mathrm{Na}$ drugim brzegu [On the other shore] includes the stories of Huang Chunming (Hwang Chun-ming) 黃春明, Bai Xianyong ( Pai Hsien-yung) 白先勇, Chen Ruoxi ( Ch’en Jo-hsi) 陳若曦, Ping Lu ( Lu Ping) (平路), Li Ang (李昂), Zhu Tianwen (Chu T'ian-wen) 朱天文 Huang Fan (黃凡) and Wu Jinfa (Wu Ching-fa) 吳錦發.

It is worth remembering that each decision determines the limitations of the reception sphere. That is why the first Taiwanese anthology in Poland is limited to contemporary stories written in Mandarin Chinese. This decision is a consequence of the publishing policy which first introduced prose fiction into the publishing market. Novels or stories by one or more authors belong to the most frequently translated literary genres. Drama, essays and poetry are significantly less popular among a Polish monolingual audience. From the perspective of the Polish reader the strategy of broad representation must win and for that reason the publisher prefers a collection of works by more than one author. It is the academic editor's responsibility to construct the collection, define the selection criteria and indicate authors and their texts. This is where the real mediation function begins. He decides what key he will use to convince the Polish reader by building the most representative picture of Taiwanese literature.

Taiwan's literature has a long history if we consider the oral myths and legends of Taiwan's indigenous peoples. Without making any final judgment about the dispute on whether or not Taiwanese literature written in hanyu is 
tributary to Chinese literature ( $\mathrm{Tu}$, "The Study of Taiwan Literature") we can certainly state that it has a distinct identity with its own historical origins and unique tradition. Thus, the question of how to build a proper representation on the assumption that the publisher prefers mainstream literature arises (Klöter 1).

Mainstream means common or popular (Yuan Kleeman 43) and limits our selection to a group of well-known writers which includes the following: Lai He 賴和 (1894-1943), Yang Kui 楊達 (1906-1985), Bo Yang 柏楊 (19202008), Zheng Qingwen 鄭清文 (Cheng Ching-wen) (1932-2017), Cheng Yingzhen 陳映真 (1937-2016), Huang Chunming 黃 春 明 (born 1935, Bai Xianyong 白先勇 (born 1937), Chen Ruoxi 陳若 䂀 (born 1938), Wang Wenxing 王文興 (born 1939), Zhang Xiguo (張系國 (Chang Hsi-kuo) (born 1944), Shi Shuqing 施淑青 (born 1945), Huang Fan 黃凡 (born 1950), Li Ang 李昂 (born 1952), Song Zelai 宋澤萊 (born 1952), Ping Lu 平路 (born1953), Zhu Tianwen 朱天文 (born 1956), Zhang Dachun 張大春 (born 1957), Wu Zhuoliu 吳濁流 (Wu Chuo-liu) (born 1956), Zhu Tianxin 朱天心 (born 1958) (Chu T'ianhsin), Wang Tuo 王拓 (born 1958), and many others.

It is clear that mainstream writers represent different periods and literary trends. We shall assume that the most important is the formative period between the 1960s and 1980s, when the literary scene was dominated by the Western-influenced modernist literary movement of the $1960 \mathrm{~s}$ and the natives' literary movement of the 1970 s. The topography of such a collection should then consider the representatives of Nativist and Modernist Literature ( $\mathrm{Tu}$, Taiwan Literature English Translation Series).

To bring the full diversity of Taiwanese literature, especially in terms of different ethnic authors, Polish editors should also consider aboriginal literature, especially oral myths and legends of Taiwan's indigenous peoples. Unfortunately it was not possible to obtain the copyright for the story Last Hunter Zuihoude lieren 最后的獵人 of Bunun writer, Tian Yage 田雅各 (Tuobasi Tapamina).

And finally, the most obvious typology based on thematic classification (Tu) must respect Urban Literature, Travel Literature, Folk Literature, Social Concerns, Political Literature Hakka Culture, Home-Nostalgia, Nature and Environment, History and Tradition and Women's Literature.The selection of Li Ang and Ping Lu of course, can or not be treated as an important strategy in pursuing the larger feminist agenda of achieving women's solidarity, Anyway, it is currently particularly useful, when the rhetoric of feminist discourse has been tightened in Poland. 
Creating literary images of Taiwan's culture and history means it is hard to overlook all religious heritage and two main literary and philosophical traditions ( $\mathrm{Tu}$, Taiwan Literature English Translation Series, No. 5) which are genetically related to the Chinese culture, namely Confucian and the still very influential Buddhist and Taoist Tradition .

For many years Taiwanese literature has been available to the international reading public. Until the time of transformation, Poles had no contact with or access to information or literature about Taiwan. In general, only researchers had access to American publications, such as a series called Modern Chinese Literature from Taiwan, published since 1997 by Columbia University Press; the journal Taiwan Literature: English Translation Series from the Center for Taiwan Studies, University of California, Santa Barbara starting in 1966 with the declared objective 'to promote a better understanding and effective knowledge among scholars abroad of the current state and tendencies of literature' (Taiwan Literature English Translation Series). Translations of Taiwan literature also appear in the quarterly bilingual periodical The Chiese PEN: Contemporary Chinese Literature from Taiwan (later renamed as Taiwan).

Enthusiasts of Taiwanese stories in the West had access to many anthologies and collections of short Stories such as New Chinese Stories: Twelve Short Stories by Contemporary Chinese Writers. 1961; New Chinese Writing [Taiwan] (1962); A Collection of Contemporary Chinese Short Stories (1971); The Muse of China: A Collection of Prose and Short Stories, (1974); Chinese Stories from Taiwan 1960-1970 (1976); An Anthology of Contemporary Chinese Literature: Taiwan, 1949- (1975); New Voices: Stories and Poems by Young Chinese Writers (1980); Bamboo Shoots After Rain: Contemporary Stories by Women Writers of Taiwan (1990); Exiles and Native Sons: Modern Chinese Stories from Taiwan (1992); Death in a Cornfield and Other Stories from Contemporary Taiwan (1994); Oxcart: Nativist Stories from Taiwan, 1934-1977 (1996); Contemporary Taiwanese Women Writers: An Anthology (2018); City Women: Contemporary Taiwan Women Writers (2001); The Last of the Whampoa Breed: Stories of the Chinese Diaspora (2003); Folk Stories from Taiwan (2005).

Many English translations of novels and collections of short stories written by famous Taiwanese writers have been published in the USA. To mention just a few: Li Ang's The Butcher's Wife: A Novel by Li Ang (1986); Zhang Xiguo Chess King (1986); Zhu Tianwen's Notes of a Desolate Man (1994); Bai Xianyong's Crystal Boys: A Novel by Pai Hsien-yung (1990); 
Taste of Apples by Huang Chunming (2001); Ping Lu's Love and Revolution: A Novel About Song Qingling and Sun Yat-sen (2006); The Orphan of Asia by Wu Zhouliu ( 2008); Li Ang's The Lost Garden ( 2015 ). ${ }^{5}$

Besides English, Taiwanese literature has also appeared in German, ${ }^{6}$ French, Italian, and Japanese. Japanese Translation project launched in 1997 and was continued until the year 2007. The process of promoting Taiwanese literature was effectively supported by Taiwanese research centers affiliated to American and European universities. Some scholars argue that the translation of Taiwanese literature into English falls into the category of 'cultural exportation', understood as a 'useful tool for identity recognition and cultural transmission, especially when a culture that is perceived as weak or small attempts to export its literature to the dominant culture' (Kung 135). ${ }^{7}$

When examining the reading preferences of the Polish reader, we can conclude that they do not differ much from the expectations of the average European reader. The statistical Polish reader is looking for scandal, exotica, fantasy, sex and crime, romance, aesthetic pleasure and aesthetic habits. Those who likes foreign literature usually prefers world bestsellers, known names and titles, especially those highly rated in rankings. Detective stories, biographies, historical books and romances are the most popular genres in Poland.

In recent years an increasing number of translations of foreign literature have gained popularity in the Polish-speaking world. However, translated Asian literature has a small market and low reception in Poland. In fact, until recently, our publishing houses were more interested in retranslation from English than in direct translation from the source language. 'Intermediate' translation of literature (Shuttleworth and Cowie 76) was cheaper and more convenient due to the possibility of using the resources of professional translators.

Most often English was a mediating source language, just like in the case of Gao Xingjian's 高行健 Soul Mountain, Lingshan 靈山 translated into Polish from the Mabel Lee's excellent English version (2000). ${ }^{8}$ Regardless

\footnotetext{
${ }^{5}$ See detailed bibliography: MCLC Resource Center. Modern Chinese Literature and Culture: Taiwan Literature, u.osu.edu/mclc/bibliographies/lit/translations-col/\#K.

${ }^{6}$ In the book by Helmut Martin, Dunsing Charlotte, and Wolf Baus Blick übers Meer. Chinesische Erzählungen aus Taiwan, Suhrkamp, 1982.

${ }^{7}$ Susan Bassnett thinks that comments describing target literature as 'young', 'weak', 'vacuum' and the like are highly subjective (Ketkar). Analysing a less typical case than Taiwan (ROC) vs. United States of America, we are dealing with a situation where it is difficult to identify a dominant and weaker culture.

${ }^{8}$ First published as Lingshan in Taiwan in 1990 by Lianjing chubanshe. Polish translation of Lingshan: Gao Xingjian. Góra duszy. Trans.Wojsław Brydak. Rebis, 2004.
} 
of the unique situations caused by political or commercial reasons, the promotion of any regional literature in Poland is mainly in the interest of the academic experts and translators. They play the key role because mostly the success or failure of a publishing house depends on them. They also know very well that the reader decodes the text according to the state of his multi-level organized consciousness. As an expert in both cultures and languages, he identifies communication opportunities. He compares the source space with the target space, analyses the broad context determined by the recipient's stereotypes, habits, symbols and experiences. At the same time, he extracts universal elements, most often emotions of sadness or nostalgia, decay of values, political ambitions, a period of struggle (Japan, GMD) and psychological portraits of peasants, workers and prostitutes. He finds literary parallels in the imaging of great transformations in Taiwan and Poland and experiences of German and Japan occupation. He appreciates exotic values of aboriginal culture, Buddhism and Taoism. In addition, translators also reveal the state of knowledge of the recipient, who usually knows something about Taiwan from Wong Kar-wai's, Hou Hsiao-hsien's films, television reports, Internet content and mainly and mostly mistakenly associating Formosa with Japanese and Korean images.

While the selection criteria in the last decade have been changed, limits still exist that will affect publisher decisions. Among the most important constraints are the difficulties of price or obtaining copyrights.

\section{TRANSLATOR AS MEDIATOR AND CREATOR}

It is worth noting once again that translation is not only the interpretation of words, sentences and meanings but also the implementation of contexts that enable the reader to gain the whole message. The translator should not only refer to the cognitive competence of the reader, but also to his knowledge, imagination, aesthetic sensitivity and literary experience.

And these are never identical. A translator, of course, assumes the intellectual capacity of a standard reader who reaches for specific literature. The author imposes a certain vision of the world on the reader. But the translator ultimately reads it and faithfully reinterprets it in the target language. Literary translation is regarded as a complex cognitive process. The translation activity starts with rendering the semantic content of the original text. Semantics is the realm of meaning Linguists distinguish different types of 
meaning: referential / denotative meaning relates to events, entities, etc.; attitudinal /connotative / expressive meaning refers to the mental state of the speaker; contextual / functional / interpersonal / situational meaning applies to the extra-linguistic situation and affects the interpretation of text.

Any level in the language, such as phonetic, lexical, grammatical, semantic and pragmatic meanings, ha its own significance because it plays a role in the total meaning Hassan (3).

Hilaire Belloc has formulated six general rules for the translator of fictional texts: 1) The translator should consider the work as an integral unit. 2) The translator should render 'idiom by idiom' and idioms of their nature demand translation into another form from that of the original. 3) The translator must render 'intention by intention', bearing in mind that 'the intention of a phrase in one language may be less emphatic than the form of the phrase, or it may be more emphatic'. 4) Belloc warns against Les faux amis, those words or structures that may appear to correspond in both source language and target language but actually do not. 5) The translator is advised to 'transmute boldly'. 6) The translator should never embellish (Bassnett 116-117).

\section{EQUIVALENCE}

In the case of literary rendition, the translator is confronted with the problem of finding equivalents not just for lexis, syntax or concepts, but also for features like style, genre, 'figurative language, historical stylistic dimensions, polyvalence, connotations as well as denotations, cultural items and culture-specific concepts and values'. (Baker and Saldanha 156)

Since Chinese language portrays the world in a diverse way and has its own grammar structure, grammar rules and syntax variance, the potential translator of Taiwanese literature must deal with missing references, untypical constructions of grammar, dialect terms, dialogues in minnan hua 閩 南話, chengyu 成語 and particular cultural references.

Because of the linguistic diversity in Taiwan, literary texts in Mandarin Chinese may include borrowings and even citations from Taiwanese Hokkien, Hakka, Japanese English, Matsu dialect and Formosan languages [mainly languages of Amis, Bunun Atayal and Paiwan] (Crook).

For instance, in Huang Chunming's short story A big cake, Da bing 大 餅, the dialogues of the father and another character are mostly in Taiwanese language (minnan hua). 
This linguistic diversity causes the translator of Taiwanese literature into Polish a transcription problem, because there are a lot of romanization systems used in Taiwan. Most often, he has the choice between respecting local transcriptions, the Wade-Giles romanization or hanyu pinyin system.

Due to these challenges the translator can easily fall into the trap of adapting the source text. ${ }^{9}$

The tendency to adapt is much more common when one translates from a language which is far-removed from the source language, like Chinese and Polish. This pair of languages may influence the mode of translation (Milton 54).

For a translator of Taiwanese or Chinese literature often regarded as 'communicators between cultures', working on cultural equivalents is more difficult than finding linguistic equivalents. From the beginning of his work on the text, he has been involved in a semiotic and symbolic network of interaction between two systems. During the process of decoding meanings in one system (Taiwanese) and encrypting in another (Polish), the notion of 'intertextuality' (Kristeva, Toporov, Genette) and dialogism (Bakhtin) are extremely significant. The clarity of this process is visible when the publisher agrees to the implementation of explanatory notes. Although they are not liked by reader, they make the work of a translator easier because he can use a technique of making explicit in the target text information that is implicit in the source text or incomprehensible for the recipient.

There are some theorists who think that 'literal translation' is not possible. However, most of them are not so rigorous and draw attention to the phenomenon of untranslatability in literary translations. ${ }^{10}$ Their position is based on linguistic relativism, which consequently leads to cultural and linguistic translation, denoting the impossibility of finding a proper equivalent. The outstanding Polish linguist and sinologist Olgierd Wojtasiewicz wrote about translation's equivalents in his book Wstep do teorii tlumaczenia [A introduction to the theory of translation] $(1957)^{11}$ and presented wrote two main obstacles to complete translatability:

1) the target language does not dispose of sufficient structural resources existing in the source language;

${ }^{9}$ Adaptation of the text has its alternative names like as recontextualization, tradaptation, spinoff, reduction, simplification, condensation, abridgement, special version, reworking, offshoot, transformation, remediation and revision (Milton 51).

${ }^{10}$ Mona Baker in her course book on translation In other words proposes the following categories of equivalence: Word Level and above Word Level; Grammatical Equivalence; Textual Equivalence; Pragmatic Equivalence (Haque).

${ }^{11}$ This book was republished in 1992 and 2005. 
2) the target language cannot be translated into certain terms designated in the source language (Wojtasiewicz 30). ${ }^{12}$

According to Wojtasiewicz's outline, the structural measures are divided into grammatical, phonetic and graphic categories. Assuming that Polish as an inflected language is more abundant in terms of grammatical measure than Chinese, the translator must choose from many structural measures available in Polish to precisely reflect the original meaning (Wojtasiewicz 48). The interpretation needs to clarify what is hidden in the vague, general formulation of the Taiwanese source text, because the structure of the Polish language forces the translator to name the unspeakable in Chinese.

Polish is characterized by a high morphological abundance, especially in the case of inflexion. In my mother tongue noun inflection indicates the person, type, number and the conjugation indicates time, case, mode, aspect and so on.

In rendering Chinese literature into Polish, the translator must often deal with problems of grammatical equivalence in terms of word-formation. Here is one of the simplest examples.

The Chinese word mao 貓 meaning cat can be translated into Polish as kot, kocur, kotka, kocica, futrzak, mruczek and the diminutive form xiaomao 小貓 as kociatko, kocurek, kiciuś, koteczek, kociak, kiciunia, kocię, kicia.

Likewise, linguistic diversity with different phonetic structures very often are the causes of mistaken translation. Although it is easy to find an equivalent for Chinese onomatopoeia, the Chinese inclination to use them frequently has a negative effect on the literary quality of the Polish text. On the other hand, it is impossible to render in Polish the graphic and sound quality of the tonal and logographic Chinese language. All literary references to the graphic forms of Chinese characters are untranslatable. In the story of Huang Chunming, mentioned above, the translator must insert original Chinese characters 言, 信, 儲 so that the reader can understand dialogue between Wan-the and a boy. ${ }^{13}$ Without the translator's footnote, the Polish reader of the anthology cannot understand either the meaning or the play of words.

Most examples indicating difficulties in choosing or lacking language equivalents can be found in the group concerning terms, anthroponyms,

\footnotetext{
${ }^{12}$ As a result, it is also impossible to translate wordplay from target to into source language.

${ }^{13}$ The dialogue between Wan-the and a boy in Big Cake is: Aren't you writing 'hsin' (信)?" „Now, I am writing 'chu'. "Which 'chu'?” When the boy pointed out the Word ,, 储 ,, in the book of him..., see: Huang Chun-min, "Big Cake". The Chinese PEN, 1998, p. 9.
} 
toponyms surnames, given names; units of measurement, architectonical names, names of the institution, names of the material culture products, names of kinship, the philosophical and religious terminology and so on. Almost every story in the anthology On the other shore has this type of expression.

For example, the title name of Li Ang's story Doll, You quxiande wawa 有曲線的娃娃 is an exemplification of the simplification of the hidden sense. In the original, the title refers to a doll with curved, gloomy shapes . On the other hand, the turtle people wugui 鳥龜 from the title Turtle clan, Wugui zu 鳥龜族 of the Wu Jinfa's story does not have a literary equivalent in Polish (e.g. neologism Żółwiołacy or Żółwiowy klan).

Many problems in the field of equivalence are caused by language allusions, erudite allusions and references to historical facts. One of many examples that can be found in the anthology is the key term wusi yundong 五 四運動 (May Fourth Movement, 1919), crucial for correct interpretation of the Bai Xianyong's story Winter Night, Dongye 冬夜.

The most difficulties, however, concern contextual and pragmatic equivalence related to the specificity of the symbolic cultures of Taiwanese inhabitants. Translating exotic realities requires the translator to have additional competencies and knowledge. Examples of Taiwanese literature with these challenges are fiction works by indigenous Taiwanese authors.

As a summary of the above comments, especially related to the significance of cultural intertextuality in the rendering process, it is worth quoting Gao Xingjian's 高行健 drama August Snow, Bayue xue八月雪 as an example. Without knowledge of the Zen Buddism history and Platform Sutra of the Sixth Patriarch, Liuzu tanjing 六祖壇經, it is impossible to translate the difficult Chinese text based on the story of Huineng (633-713) 惠能, the Six Patriarch of Chan Buddhism and founder of the Sudden Enlightenment School $^{14}$.

${ }^{14}$ The première of the Snow in August, written and directed by Gao Xingiian, took place in Taipei on December 19th 2002. The Taiwanese press highlighted the preparation of this unusual opera. Although Gao Xinjian is not a Taiwanese writer, many of his works in Chinese were published after 1989 in Taiwan. 


\section{BIBLIOGRAPHY}

As-Safi, Abdul B. "Translation Theories, Strategies And Basic Theoretical Issues," 2011. Akademia, www.academia.edu/6395785/Translation_Theories_Strategies_And_Basic_Theoretical_Issue. Accessed 14.11.2021.

Bakhtin, Michail. The Dialogic Imagination: Four Essays. University of Texas Press, 2010.

Baker, Mona. In other words: A Coursebook on Translation. Linguistics/Translation studies. Routledge, 1992.

Baker, Mona, and Gabriela Saldanha, editors. Routledge Encyclopedia of Translation Studies. Routledge, 2009.

Bassnett, Susan. Translation Studies. $3^{\text {rd }}$ ed. Routledge, 1988.

Bassnett, Susan, and Harish Trivedi. Post-Colonial Translation: Theory and Practice. Routledge, 1999.

Jabłoński, Witold. „Zagadnienia przekładów z języków orientalnych zilustrowane na materiale chińskim”. O sztuce thumaczenia, edited by Michał Rusinek. Ossolineum, 1955, pp. 59-84.

Jakobson, Roman. "On Linguistic Aspects of Translation". On Translation, edited by Reuben Brower. Harvard University Press, 1959, pp. 232-239.

Catford, J.C. A Linguistic Theory of Translation. Oxford University Press, 1965. Internet Archiv, archive.org/stream/J.C.CatfordALinguisticTheoryOfTranslationOxfordUniv.Press1965/j.+c. + catford-a+linguistic + theory + of + translation-xford + univ. + press $+\% 281965 \% 29$ djvu.txt. Accessed 14.11.2021.

Crook, Steven. "Translation projects unlock world of Taiwanese literature." Taiwan Today, March 18, 2011, taiwantoday.tw/news.php?unit=18\&post=24446. Accessed 14.11.2021.

Even-Zohar, Itamar. "The Position of Translated Literature within the Literary Polysystem." Translation: Theory and Practice: A Historical Reader, edited. Daniel Weissbort and Astradur Eysteinsson, Oxford: Oxford University Press, 2006, pp. 429-434.

Genett, Gérard. Einführung in den Architext, trad. Fr. Introduction à l'architexte. Legueil, 1990.

Haque, Md. Ziaul. "Translating Literary Prose: Problems and Solutions." International Journal of English Linguistics, vol. 2, no. 6, 2012, ccsenet.org/ijel, www.translationdirectory.com/ articles/article2360.php. Accessed 14.11.2021.

Hassan, Bahaa-eddin Abulhassan . Literary Translation:Aspects of Pragmatic Meaning. Cambridge Scholars Publishing, 2011.

Hodges, Peter. "Linguistic Approach to Translation Theory." 2009. TranslationDirectory.com, www.translationdirectory.com/articles/article2019.php. Accessed 14.11.2021.

Jureczek, Paweł . "Literary Translation Quality Assessment: An Approach Based on Roland Barthes' Five Literary Codes." Translatologica (Journal of Tranlation, Language and Literature), vol. 1, 2017, pp. 136-155.

Ketkar, Sachin. "Literary Translation: Recent Theoretical Developments," 2005. Translation Directory.com, www.translationdirectory.com/article301.htm. Accessed 14.11.2021.

Kittel, Harald, editor. International Anthologies of Literature in Translation. Beiträge zur internationalen Bersetzungsforschung. Erich Schmidt Velag, 1995.

Klöter, Hennig. "What is the Mainstream in Taiwanese Literature: An Introduction." Studia Orientalia Slovaca, vol. II.I, 2012, pp. 1-4.

Kristeva, Julia. Desire in Language: A Semiotic Approach to Literature and Art. Blackwell, 1980. 
Kung, Szu-wen C. "Translation agents and networks, with reference to the translation of contemporary Taiwanese novels". Translation Research Projects 2, edited by Anthony Pym and Alexander Perekrestenko . University Rovira and Virgili, 2009, pp. 123-138.

Larson, Milded L. Meaning-Based Otranslation: A guide to Cross-Language Equivalence. University Press of America, 1998.

Lu, Chun-yu. "Taiwan's literature translated.” www.culture.tw, 19 September 2007, Accesed 10.09.2019.

Malmkjar, Kirsten. "Unit of Translation.” Routledge Encyclopedia of Translation Studies, edited by Mona Baker Routledge, 1998, pp. 286-288.

Martin, Helmut, Charlotte Dunsing and Wolf Baus. Blick übers Meer. Chinesische Erzählungen aus Taiwan. Suhrkamp, 1982.

MCLC Resource Center Modern Chinese Literature and Culture: Taiwan Literature, U.OSU (Ohaio State University), u.osu.edu/mclc/bibliographies/lit/translations-col/\#K. Accessed 14.11.2021.

Milton, John. "Translation Studies and adaptation". Translation research projects 2, edited by Anthony Pym and Alexander Perekrestenko, Universitat Rovira i Virgili, 2009, pp. 51- 58.

Na drugim brzegu. Antologia wspótczesnych opowiadań tajwańskich [On the other shore: Anthology of Contemporary Taiwanese Short Stories], edited by Lidia Kasarełło, Państwowy Instytut Wydawniczy, 2020.

Newmark, Peter. Approaches to Translation. Pergamon Press, 1981.

Niranjana, Tejaswini. Siting Translation: History, Post-Structuralism, and the Colonial Context. Orient Longman, 1995.

Paper Republic: Chinese Literature Matters, paper-republic.org/publishers/taiwan- literatureenglish-translation-series. Accessed 7.09.2019.

Pisarska, Alicja, and Teresa Tomaszkiewicz. Współczesne tendencje przekładoznawcze. Wydawnictwo Naukowe Uniwersytetu im. Adama Mickiewicza, 1996.

Schulte, Rainer. "International Literature Transfer via Translation Anthologies." International Anthologies of Literature in Translation, edited by Harald Kittel, Erich Schmidt Verlag 1995, pp. 134.

Schulte, Rainer. The Geography of Translation and Interpretation: Traveling Between Languages, E. Mellen Press, 2001.

Shuttleworth, Mark, and Moira Cowie. Dictionary of Translation Studies. St. Jerome Publishing, 1997.

Spivak, Gayatri Chakaravorty. "The Politics of Translation". Translation: From Periphery to Centerstage, edited by Tutun Mukherjee, Prestige, 1998, pp. 95-118.

Steiner, George. After Babel. Oxford University Press, 1975.

Toury, Gideon. Descriptive Translation Studies and Beyond. John Benjamins, 1995.

Tu, Kuo-ch'ing, and Robert Backus, editors. "Taiwan Literature: English Translation Series." Center for Taiwan Studies, taiwancenter.eastasian.ucsb.edu/publications/ets. Accessed 14.11.2021.

Tu, Kuo-ch'ing . "The Study of Taiwan Literature: An International Perspective", 1997. Center for Taiwan Studies, taiwancenter.eastasian.ucsb.edu > publications. Accessed 14.11.2021.

Tu, Kuo-ch'ing. "Literature and Social Concerns, preface Taiwan Literature.” English Translation Series, No. 5. taiwancenter.eastasian.ucsb.edu/sites/secure.lsit.ucsb.edu.east.d7. Accessed 14.11.2021.

Venuti, Lawrence, ed. The Translation Studies Reade. Routledge, 2000. 
Vinay, Jean-Paul and Darbelnet Jean. Comparative Stylistics of French and English: a Methodology for Translation. John Benjamins, 1995.

Wilss, Wolfram. Knowledge and Skills in Translator Behaviour. John Benjamins, 1996.

Wojtasiewicz, Olgierd. Wstęp do teorii thumaczenia. Wydawnictwo TEPIS, 2005. $1^{\text {st }}$ edition: Ossolineum, 1957.

Yuan Kleeman, Faye. "Off the Beathen Path: (post)-Colonial Travel Writings on Taiwan." Studia Orientalia Slovaca, vol. II.I, 2012, pp. 43-64.

\section{WPROWADZANIE PRZEKŁADÓW \\ WSPÓŁCZESNYCH TAJWAŃSKICH OPOWIADAŃ W POLSCE. KONTEKSTY KULTUROWE, POLA REPREZENTACJI I EKWIWALENCJA}

\section{Streszczenie}

W artykule omówiono podstawowe zagadnienia związane z thumaczeniem literatury tajwańskiej w Polsce. Przyjmując definicje Juliane House, że przekład jest „procedurą poznawczą i praktyką społeczną, międzyjęzykową i międzykulturową", omawiam kwestię teoretycznie i praktycznie na trzech głównych poziomach dotyczących literatury i komunikacji między językami i kulturami. Zgodnie z podejściem systemowym model dzieli się na: 1) Źródło/Litertura tajwańska; 2) Cel/Czytelnik polski; 3) Mediacja/Tłumacz i jest nasycona refleksją na temat reprezentacji, kontekstu kulturowego i politycznego oraz równoważności w polisystemie przekładu. W wymiarze praktycznym analiza odnosi się do konkretnego przypadku, jakim jest przygotowanie pierwszego polskiego przekładu tajwańskich współczesnych opowiadań. Omawiana antologia współczesnych opowiadań tajwańskich powstaje z perspektywy tłumaczy, którzy są sinologami wykładającymi na Uniwersytecie Warszawskim. Zgodnie $z$ koncepcjami teoretyków antologii tego rodzaju akademickie wydanie z odniesieniami i krytycznymi komentarzami wspiera polskiego czytelnika w procesie poprawnego dekodowania tekstu i wielu kontekstów literatury tajwańskiej.

Słowa kluczowe: thumaczenie; literatura tajwańska; polski odbiorca; reprezentacja; ekwiwalencja; mediacja międzykulturowa; Antologia opowiadań tajwańskich. 